\title{
腹腔鏡下レーザー手術 一他の機器との比較検討一
}

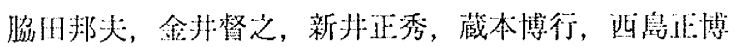

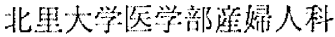

\author{
Laparoscopic Laser therapy - Comparative study between Lasers and the other \\ equipments - \\ Kunio Wakita, Tadayuki Kanai, Masahide Arai, Hiroyuki Kuramoto, Masahiro Nishijima \\ Department of Obstetrics and Gynecology, School of Medicine, Kitasato University
}

\begin{abstract}
Operative laparoscopy was performed on ninety-eight cases with gynecologic benign disease. Lasere euipments (Nd:YAG,KTP/YAG,Ho:YAG),electrocautery (monopolar, bipolar, Argon beam coagulator) and Harmonic scalpel were used. For the treatment of ovarian cyst, drainage, ethanol fixation, ablation of lining, stripping of lininig (intra orextracorporeal) and adnexectomy were performed on them. For adhesion, lysis, and/or TUSL (Transection of Utero Sacral Ligament) were carried out. For myoma, adenomyosis, carcinoma in situ of uterine cervix and descensus uteri with adhesion, LAVH (Laparoscopically Assisted Vaginal Hysterectomy) were carried out.

In the group of endometriosis with endometrioma, $69.2 \%$ (18 of 26) reported over $50 \%$ pain relief and $11.5 \%$ ( 3 of 26 ) reported no pain from menstrual pain after the surgery. Recurrent endometrioma was found in $42.3 \%$ (11 of 26). In the group of endometriosis, $71.4 \%$ (15 of 21 ) reported over $50 \%$ pain relief and $23.8 \%$ ( 5 of 21 ) reported no pain from menstrual pain. In the group of pelvic inflammatory disease and dysmenorrhea, $57.1 \%$ (4 of 7) reported over $50 \%$ pain relief and $28.6 \%$ ( 2 of 7 ) reported no pain from menstrual pain. In the group of ovarian cyst, recurrent cyst was found in $5.9 \%$ (1 of 17). All patients after the LAVH had no complaints.

Their complications during and after the operation were minimal. There was no difference between the Laser group and the other group in the results and complications.
\end{abstract}

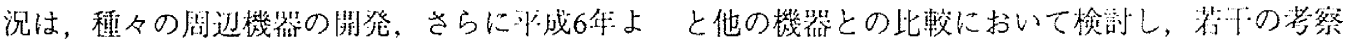

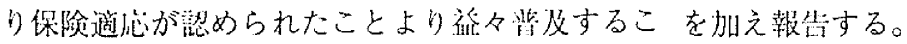


II 刘笔

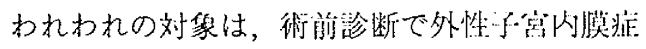
64例（チョコレート壊胞合侀あり：29，なし：35），

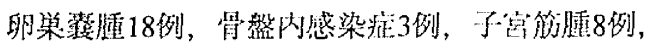

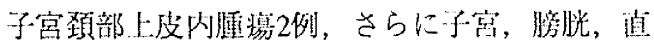
览下重3例，計98例だった。尚，これらには，挙 児希望のため積極的な不弤検査を希望するものは 含まれていない。

\section{III 方法}

1 使用機器

レーザーでは, Nd:YAG, KTP/YAG, さらにHo: YAGレーザーを使用した。前2者では, ベアファ イバーによる拉触性及び非接触性照射を, 後者で

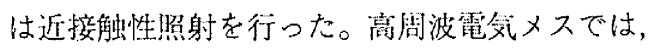
モノポーラー及びバイポーラー䉓極を使用した。 さらに, Argon beam coagulatorも伐用した。また, 超至波切開凝固システムであるハーモニック・ス カルペルも応用した。

\section{2 治療法}

以下の治潦法は，術後邶断による。

1）外性子宫内脱症及び有捎性月経

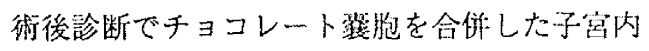
膜症34例には，䈱胞內容吸引洗淮（13例），工夕 ノール固定術（2例），籍胞内倿烧灼術（2例）, 籍胞切除術（2例），籍胞核出術（腹坨内5例，腹 控外4例），付属器切除術（5例）を行った。残り

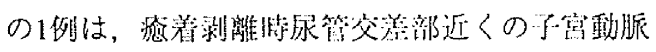
の枝よりの出卹のため關腹術となった。

内膜症のみの26例には，牕着剥離術（4例）， +Transection of UteroSacral Ligament (以下, TUSL. 20例），電気熺灼術+TUSL（2例）を施行した。

有痛性月経の4例には, 看着剥陮術（1例）, TUSL（3例）を行った。

2) Fitz Hugh Curtis Syndrome及び卯管溜澧脽 前者の2例には，满着剥離術を，後者の2例には 各々卵管開口術と卵管切馀術+楒着剥離術を行っ た。

3) 卵樂謷徆

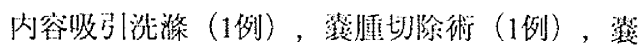

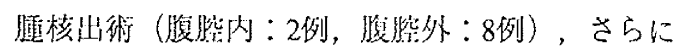
付属器切除術（5例）を行った。

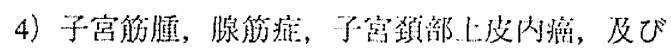

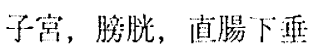

子宫筋腫には，3例にLAVH（Laparoscopically Assisted Vaginal Hysterectomy）を，3例にLAVH+婳 付属器切除術を施行した。.上皮内癌の2例には, LAVH+雨付属器切除術を施行した。3例の子究, 膀胱, 及び直晹下垂には, LAVH+两付属器切除術, 㓐前後照形成術を施行した。

\section{IV 成維}

以下の成績は, 術後街断による。

1 外性子宮内膜症+チョコレート壊胞

1 例の開腹手術例，7例の偽閉経療法中例之脱落 例を除いた26例中の月経痛の改善は，すべてに楒 められた。69.2\%（18例）は治㜣前に比し50\%以 上の改善が，11.6\% (3例) は消失した。賴胞の再

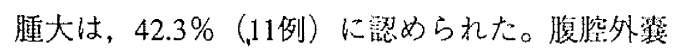
胞核出術を行った1例は，現在妊娠経過中である。

2 外性子宮内膜症

計5例の偽閉経中例と脱落例を除いた21例中の 月経痛の改善は, すべてに瑟められた。71.4\%

（15例）は，50\%以上の改善が，23.8\%（5例）は 消失した。うち1例には，経腔分㚾を経験した。

3 Fitz Hugh Curtis Syndrome, 卵管溜胀腫, 及び 有痛性月経

偽閉絴潦法中の1例を除いた7例が，評湖叮能だっ た。月経痛の改攵は, 有痛性月緦の1例を除いた6 例に翗められた。 $57.1 \%$ (4例)は, $50 \%$ 以上の改 普が，28.6\%（2例）は，消失した。

4 卵巣潔腫

贅腄内容吸引洗涤を施行した1例を除いた $94.1 \%$ に再腫大は認めていない。うち2例は妊娠中であ る。

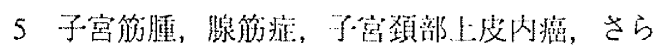
に子窎，膀脱，㨁晹下垂

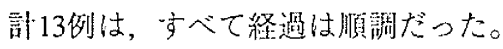


$\mathrm{V}$ 副作用

\section{1 術中}

術中の副作用では，計15.3\%（14例）に楒めら れた。これらの内訳は，LAVHの腔前壁形成術特， 電メスの接触による外除の小火惶が1例, 掏着渌 離洔, 子宮動脈と尿管管差部近くの動脈より出血 のため, 開腹して止扎操作を行った1例だった。 また，腹壁 $10.5 \mathrm{~mm}$ のトロッカー架刺部よりの出血 のため, 処䈯を要したものが例, 皮下気腫が7例 だった。無気肺を1例経験したが，本例はトロッ カー等刺部よりの出血と皮下気腫を重複していた。 さらに銝子による子宫後壁損傷を1例経験した。

\section{2 術後}

術後では，腹壁トロッカー挿入部の感染を2例， 同創部の小血腫を1例，さらに皮下出I血を3例，計 6例 $(6.1 \%)$ 経験した。

\section{VI 考察}

当初われわれは，ベアファイバーを利用したNd: YAGレーザーによるレーザーラパロスコピー1) を行っていた。先端径 $0.6 \mathrm{~mm}$ と練いため, 出力 10 〜15wattsでも切除も止血凝国もほほ满足できるも のだった。その後, 臨床治験としてKTP/YAGレー ザー2）を使用したが，さらに有用と思われた。 一方，同棁に臨柇治験を行ったHo:YAGレーザー3） は，波長の特徵とは異なり，臨床、上はKTPレーザー ほど切開能は良好ではなかったが，止佔能は高かっ た。

近年，欧米特に米国では，注に経済的理由から 高周波電気入ス，特にバイポーラー4）の使用頻

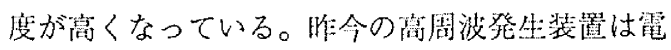

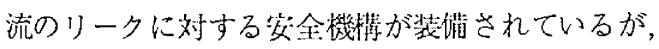
层管や晹管が近接する場合には，十分注億が必要 である。その際は, バイポーラーでも安全とは言 えない。レーザー, 特にKTPレーザーはより安心 して使用することが出来る。本乎，英国ロンドン で開催された第4回国際婦人科内視鏡学会では,
バイポーラーで切開も组来る器具を使用した報告 5）も兒られ，今後有望と思われる。Argon beam coagulator は，組織の表面のみを浅く（約1 $\mathrm{mm}$ ) 焼灼できるため，ブルーベリースポットやチョコ レート䠣胞の内腔を烧灼するの有用だった。

Harmonic scalpelは, 先端の振動で切開抢よび凝固 するため，電気メスに比し安全ではあるが，厚い 組織の切開には㬨間を姴するのが難点である。し かし, 止佔効果は高かった。

腹臆鏡下で行ったわれわれの手技は全般に極め て優秀だった。しかし，チョコレート晸胞では， 開始当初, 資胞内容吸引洗淡を行った13例中7例 に再腫大が認められたことより，明今は保存的に は核出術を，根治的には切除を行うことにより改 善されている。

レーザーは極めて高栣のため, 種々の機器を購 入することは困難である。一つのレーザー習熟す ることが, 副作用の予防の観点からも重要と思わ れた。今後, レーザー機器のさらなるコンパクト 化と，安価なものの開発を期街したい。

文献

1）脇田邦夫，他：婦人科における新しいFiber -optic laser laparoscopyの試み，第11回日本レ 一ザー医学会大会論文集, 449 452, 1990.

2) Wakita K.et al : Clinical Investigation with KTP/YAG Laser for Lower Genital Tract Disease. J.Clin.Laser Med. Surg, 10(1):7〜11, 1992.

3）脇田邦夫，他：レーザーによる腹㟐鏡下手術。 日本レーザー医学会誌，15（4）：31〜37, 1994.

4) Phillips D.R.:Laparoscopic leiomyoma coagulation(myolysis).Gynaecological Endoscopy, 4(1): $5 \sim 11,1995$.

5) Daniell J.F.:Laparoscopic use of a bipolar needle for neosalpingostomy. 4th Biennial meeting of the international society for gynecologic endoscopy, abstract,P.22,1995. 